\title{
German Religious Emblems As Stimuli of Visual Culture in the Dutch Republic
}

\author{
Feike Dietz, Els Stronks
}

\begin{abstract}
The existing studies into Dutch translations of German religious texts suggest that literaryreligious culture in the Dutch Republic did not undergo significant transformation during the course of the seventeenth century as a result of German-Dutch exchange. There is even more reason to assume that German illustrated religious literature remained out of the focus of Dutch audiences: visual additions to religious texts, popular in German publications as a result of the Lutheran approach to word-image interaction, encountered resistance in the Dutch Republic where the development of illustrated religious literature was restricted and delayed compared to the Republic's neighbouring countries. A closer look at two cases of German-Dutch literary exchange in the field of religious emblematics suggests that the restrictive Dutch visual practices were at times stimulated and innovated by the import of German models. The two cases discussed in this article give us reason to advance the very tentative hypothesis that the German-Dutch contact was at times critical to the growth of the use of religious imagery in Dutch religious literature. Finally, a case is made in favour of attending more to the international exchange of religious imagery in order to chart the impact of the Reformation in Northern Europe.
\end{abstract}

\section{Keywords}

religious illustrated literature; German-Dutch exchange; word-image interaction; Reformation; visual practices

Recently, the mutual exchange between the early modern literature from Germany and the Dutch Republic has been an area of interest to literary scholars, church historians, and cultural historians. Research has focused on German translations and adaptations of successful seventeenth-century Dutch authors such as Jacob Cats, Joost van den Vondel, and Daniel Heinsius, and on Dutch translations of eighteenth-century German literature. ${ }^{1}$ The existing research

1) Seventeenth-century German translations have been studied in Niederländisch-Deutsche Kulturbeziehungen I600-I830, ed. Jan Konst, Inger Leemans, and Bettina Noak (Göttingen, 
creates the general impression that during the seventeenth century, Dutch literature served as a model of inspiration for German authors. These roles reversed in the eighteenth century when German authors became leading authorities for their Dutch counterparts.

This general pattern certainly appears to hold true for the religious literature produced in both countries during the seventeenth century. The existing studies into Dutch translations of German religious texts suggest that literaryreligious culture in the Republic did not transform significantly during the course of the seventeenth century as a result of German-Dutch exchange. In fact, if the number of translations is taken as a point of reference, the transfer of German literature into the Republic's literary culture was virtually nonexistent. Dutch adaptations of the devotional work of the German Lutheran writer Johann Arndt were indeed published in the Dutch Republic, but were never reprinted because of a lack of interest. ${ }^{2}$ Nor did the Dutch translations of Johannes Heidfeldius's work, by the Amsterdam publisher Dirck Pietersz. Pers, receive a warm welcome in the Republic. Other religious works Pers published-not translations from German examples, but new productionsbecame much more popular, judging by the number of reprints he produced. ${ }^{3}$

2009), and Ferdinand van Ingen, 'Philipp von Zesen als Übersetzer von Jacob Cats (I 67I),' in Niederländische Lyrik und ihre deutsche Rezeption in der Frühen Neuzeit, ed. Lothar Jordan (Wiesbaden, 2003), pp. I77-192. A NWO project by Jan Bloemendal, titled 'Dynamics of Neo-Latin and the Vernacular. The interplay between Latin and Dutch poetry of the Seventeenth century and their reception in German speaking countries (2010-2014),' is also devoted to this subject. Eighteenth-century Dutch translations of German originals have been the focus of attention of scholars such as Joris van Eijnatten (see Van Eijnatten's 'History, Reform, and Aufklärung. German Theological Writing and Dutch Literary Publicity in the Eighteenth Century,' Journal for the history of modern theology 7 (2000), 173-204, and 'German Paratexts, Book Reviews and Dutch Literary Publicity. Translations from German into Dutch, I76 I-I 796,' Wolfenbütteler Notizen zur Buchgeschichte 25 (2000), 95-I 27). Inger Leemans also focuses on eighteenth-century translations as a Postdoc on the NWO project 'The cultural influence of the German-speaking countries in the Netherlands between 1750 and I 850 : Repercussions on the arts, the literary field and the printed media', Leemans departs from the assumption that Dutch culture first became increasingly and profoundly influenced by the culture of the German lands during 1750-1840, in all fields of the humanities (philosophy, literature, arts).

2) Ferdinand van Ingen, 'De receptie van Johann Arndt in Nederland,' Documentatieblad Nadere Reformatie 29 (2005), 3-1 5.

3) The Dutch translation of Heidfeldius's Sphinx theologico-philosophica was published three times (in I6I 2, I627, and I658), titled Schriftuerlijcke ende philosophische tijt-korter (see the 
There is ample evidence that Dutch audiences were especially hesitant to embrace German illustrated religious literature. An attempt by the Germanborn Dutch Reformed minister Johannes Möller to introduce Dutch readers to the German tradition of the biblical ars memorativa, which derived from the interplay between emblematic imagery and mnemonics, encountered severe resistance from the Dutch Reformed Synods. Möller's picture Bible, Sleutel, dewelke verklaard de bybelse figuuren oover de vier evangelisten, Handelingen der Apostelen en Openbaaringe Johannis ( I682) [Key, which explains the Biblical Figures concerning the Four Gospels, Acts of the Apostles, and the Book of Revelation], was a Dutch translation of a German edition from I68I. Both editions were produced in Leiden. Illustrated with fold-out biblical prints with emblematic and allegorical details, the book was severely criticized by Möller's Dutch Reformed colleagues because of the imagery it contained. This criticism resulted in Möller's decision to take all copies off the market at his own expense and to his own detriment. Möller also promised not to make any further attempts to deal with theological issues in such a visual manner. ${ }^{4}$ To all appearances, other Dutch publishers tried to avoid the kind of criticism Möller's picture Bible received. Geissmar's inventory of illustrated editions of the mystical works of the German Pietist Jacob Böhmealmost all of which were produced in the Republic — reveals that the editions intended for a Dutch audience used far less emblematic imagery derived from Catholic traditions than did German editions intended for German audiences. $^{5}$

The results of our recent research indicate that the resistance against German illustrated religious texts can be related to a wider context. In the Dutch Republic, visual components were not easily integrated in literary-religious publications. Many more or less official statements condemning the Catholic use of images, issued by the Dutch Reformed Church over the course of the seventeenth century, imposed restraints on literary practices of authors,

Short Title Catalogue Netherlands for details), but it never became one of Pers's bestsellers. His religious song book, Bellerophon of lust der wijsheyd, was one of his untranslated religious publications that did become very popular.

4) Huigen Leeflang, 'Waarheid, vlugheid en inventie: ontwerp en uitvoering van de etsen,' in Romeyn de Hooghe: de verbeelding van de late Gouden Eeuw, ed. Henk van Nierop et al. (Zwolle, 2008), pp. I 26-I 45, en Els Stronks, 'Het beeld bij het Woord onder gereformeerde censuur,' Delineavit et Sculpsit 34 (2010), 8-19.

5) Christoph Geissmar, Das Auge Gottes: Bilder zu Jakob Böhme (Wiesbaden, I993). 
publishers, and printers of all denominations. The restrictions apparently applied to authors of all denominations, not just to the ones affiliated with the Dutch Reformed Church. Dutch authors were all guided and limited by restrictive views-inspired by Calvinist theology regarding the use of religious imagery. ${ }^{6}$ Even the Catholic authors in the Republic seemed reluctant to adopt religious imagery. ${ }^{7}$ As a consequence, Bible illustrations were not incorporated in full Bible translations printed by Protestants in the Dutch Republic in the seventeenth century. ${ }^{8}$ The development of the religious emblem was even more problematic, although the emblem itself was one of the major sources of visual expression in the Dutch Republic. After some debate, a widespread agreement was reached entailing that Biblical illustrations could be tolerated as long as they were included in picture Bibles, and as long as they did not include allegorical elements or anthropomorphic representations of God. Biblical illustrations were tolerated because they were perceived as relatively comprehensible, literal representations of biblical stories. Emblematic, allegorical images were regarded with great suspicion because visual stimuli required human capacities to interpret, thus increasing the chances of misinterpretation. As a result of this suspicion, Dutch religious emblematics only began to flourish towards the end

6) Dutch sixteenth-century disputes on the issue had already been dominated by Calvinist theology, see Ilja Veldman, 'Protestantism and the Arts: Sixteenth and Seventeenth-Century Netherlands,' in Seeing Beyond the Word: Visual Arts and the Calvinist Tradition, ed. Paul Corby Finney (Grand Rapids, I999), pp. 397-42 I. See also Randall C. Zachman, Image and Word in the Theology of John Calvin (Notre Dame, 2007). On the laborious acceptance of the religious emblem by the Dutch Reformed, see Els Stronks, 'Literature and the Shaping of Religious Identities: the Case of the Protestant Religious Emblem in the Dutch Republic,' History of Religions 29:3 (2010), 219-253.

7) The caution that Catholics exercised towards Southern Netherlandish Catholic emblematic traditions is discussed in Feike Dietz, 'Under the Cover of Augustine. Augustinian Spirituality and Catholic Emblems in the Dutch Republic,' forthcoming; and Feike Dietz, 'Dark Images, Clear Words. Pieter Paets's Illustrated Devotional Literature From the Missio Hollandica,' in Discourses of Meditation in Art and Literature, I300-I600, ed. Karl Enenkel and Walter S. Melion [Intersections I7] (Leiden, 2010), pp. 29 I-320. See also Karel Porteman and Mieke B. Smits-Veldt, Een nieuw vaderland voor de muzen. Geschiedenis van de Nederlandse literatuur, I560-I700 (Amsterdam, 2008), p. 477.

8) As argued in Peter van der Coelen, De Schrift verbeeld: Oudtestamentische prenten uit renaissance en barok (Nijmegen, I998), passim; Bart Rosier, The Bible in Print: Netherlandish Bible Illustration in the Sixteenth Century, 2 vols. (Leiden, I997), I: 35, 47, I I7, I 2 I, and I37; and Walter S. Melion, 'Bible Illustration in Sixteenth-Century Low Countries,' in Scripture for the Eyes. Bible Illustrations in Netherlandish Prints of the Sixteenth Century, ed. Walter S. Melion (New York, 2009), pp. 42-45. 
of the seventeenth century, at the same time that new impetus was being given to Bible illustrations in the work of Jan Luyken, Bernard Picart, and Romeyn de Hooghe. ${ }^{9}$

Therefore, from an international perspective it becomes apparent that Dutch literary practices differed from those in other Northern European countries, where the cross-fertilization of Catholic and Protestant religious literary practices started while iconoclastic acts were still being staged. After I600, religious emblematics were thriving in neighbouring countries such as the Southern Netherlands, England, France, and Germany, and the production of illustrated Bibles flourished outside the Dutch Republic. Recent research has focused on identifying degrees of continuity and gradual transformation in the English and German literature: Chloe Porter has demonstrated that early modern English drama draws on notions of viewer agency fostered by idolatrous and iconoclastic visual experiences, thus supplementing and reinforcing the research results of art historians and historians, which indicate that despite underlying theological differences, a meaningful and acceptable transformation of Pre-Reformation and Catholic visual practices was sought by Protestants artists and authors. ${ }^{10}$ As widely established, the Lutheran approach to word-image interaction in religious art that dominated German cultures facilitated such forms of integration: the Lutherans' negotiation of the theology of images developed a reformed art among Lutherans and Catholics alike, stimulating the development of illustrated religious texts. ${ }^{11}$ As Koerner has argued,

9) On the rise of the religious emblem at the end of the seventeenth century, see Els Stronks, 'Dutch Religious Love Emblems. Reflections of Faith and Toleration in the later seventeenth century,' Literature and Theology 23:2 (2009), I 42-164. For a more detailed analysis of these developments and views, see Els Stronks, Negotiating Differences: Word, Image and Religion in the Dutch Republic (Leiden, 201 I).

10) Chloe Porter, 'Idolatry, Iconoclasm and Agency: Visual Experience in Works by Lyly and Shakespeare,' Literature \& History I 8: I (2009), I-I 5. Other recent contributions to this debate are: David Davis, 'Images on the Move: The Virgin, the Kalendar of Shepherds, and the Transmission of Woodcuts in Tudor England,' Journal of the Early Book Society (2009), 99-I 29; Alexandra Walsham, 'Unclasping the Book? Post-Reformation English Catholicism and the Vernacular Bible,' Journal of British Studies 42 (2003), I4I-166, inspired by Tessa Watt, Cheap Print and Popular Piety, I550-I640 (Cambridge, I99I).

11) See Charles Zika, 'Writing the Visual into History. Changing Perceptions of Late Medieval and Reformation Germany,' in Exorcising our Demons: Magic, Witchcraft, and Visual Culture in Early Modern Europe (Leiden, 2000), pp. 523-55 I; Keith Moxey, Peasants, Warriors, and Wives: Popular Imagery in the Reformation (Chicago, I989); Robert W. Scribner, For the Sake of Simple Folk. Popular Propaganda for the German Reformation (Cambridge, 
as early as the sixteenth century, Lucas Cranach's Protestant paintings deliberately suppressed the emotional appeal of his earlier work in order to reduce the threat of an idolatrous response.

When the restrictive features of the Republic's literary culture are viewed from an international perspective, it becomes apparent that the impasse in the development of illustrated religious literature in the Dutch Republic was exceptional. Religious literature produced in the Dutch Republic throughout most of the seventeenth century contained far fewer illustrations than the literature of neighbouring countries. ${ }^{12}$ Considering the relative freedom with which different denominations and their attendant ideologies coexisted in the seventeenth-century Dutch Republic, ${ }^{13}$ and the very few public and official restrictions in the production of religious literature, this impasse in the development of a visual literary culture is remarkable. ${ }^{14}$ It can only be explained by the assumption that what hampered the development of religious literature must have been sensibilities - unwritten rules of behaviour and decorum which determined what could and could not safely be done and said in Dutch society. ${ }^{15}$

I98I); Joseph Leo Koerner, The Reformation of the Image (London, 2004); and William A. Dyrness, Reformed Theology and Visual Culture: The Protestant Imagination from Calvin to Edwards (Cambridge, 2004).

12) Such was already the case at the end of the sixteenth century, as argued in Andrew Pettegree, Reformation and the Culture of Persuasion (Cambridge, New York, 2005), p. 106. 13) Benjamin Kaplan has recently referred to the Dutch Republic as an example of a liberal "religious melting pot," in which people from different denominations participated in a common society and culture. In that crucible, religious toleration was a practical form of behaviour: "the peaceful coexistence of people of different faiths living together." Benjamin J. Kaplan, Divided by Faith. Religious Conflict and the Practice of Toleration in Early Modern Europe (London, 2007), pp. 240 and 8. On the absence of a dominant cultural model in the Dutch Republic see also Willem M. Frijhoff, 'Was the Dutch Republic a Calvinist Community?: The State, the Confessions, and Culture in the Early Modern Netherlands,' in The Republican Alternative: The Netherlands and Switzerland compared, ed. André Holenstein, Thomas Maissen, and Maarten Prak (Amsterdam, 2008), pp. 99-I22; and Willem M. Frijhoff, Marijke Spies, and Wiep van Bunge, Dutch Culture in an European Perspective. Hard-Won Unity, I65o (Assen, Basingstoke, 2004).

14) Ingrid Weekhout, for instance, has reported only incidental and small-scale cases of censorship: Ingrid Weekhout, Boekencensuur in de Noordelijke Nederlanden: de vrijheid van drukpers in de zeventiende eeuw (Den Haag, 1998).

15) See Etienne François, Die unsichtbare Grenze: Protestanten und Katholiken in Augsburg I648-I806 (Sigmaringen, I99I). 
In these circumstances, it is hardly surprising that German illustrated texts such as Möller's emblematic picture Bible were not cordially received. However, a closer look into forms of German-Dutch literary exchange, as presented in this article, reveals that although exchange between the German illustrated religious literature and the predominantly unillustrated Dutch religious literature seldom occurred, contact between the two was at times critical to the development of Dutch visual culture. We contend that the two cases discussed in this article demonstrate that German impulses led to significant innovations in Dutch religious emblematics in the seventeenth century. These two cases give us reason to advance the very tentative hypothesis that the growth of the use of religious imagery in Dutch religious literature was stimulated by German-Dutch contact, specifically through the attempts of a number of individual Dutch authors and publishers who introduced German translations and adaptations of religious emblem books based on Catholic iconography into the Dutch Republic.

The following section will focus on just a small segment of the German impulses, for we employ only examples from the Dutch Reformed tradition. In our conclusion, we will relate the results of our limited investigation to the larger question concerning the significance of foreign stimuli to the development of visual literature in the Dutch Republic, and speculate as to what insights could be gained by examining the crosscurrents of religious imagery on an international scale.

\section{Religious Emblematics in Northern Europe}

After I600, the religious emblem in Northern Europe prospered with the assistance of Catholics who deployed the genre as a tool in the enhancement of the communication between God and the believer. A special iconography was developed to this end, characteristics of which have recently been analyzed and emphasized by art historians such as Ralph Dekoninck and Walter Melion. They show that the images in these emblem books visualize what the accompanying meditative texts describe. In response to the texts, viewers were encouraged to identify directly with the depicted figures, to consider the figures as representing themselves. Images were understood to engage the cognitive and affective faculties of memory, mind, and will-a meditative process by which one could get to know his or her own soul, enabling the soul to refashion itself. The constant interaction between image and word in these prints was intended to guide viewers meditative exercises. This use of images proceeded from complex theories on visuality and 
the applicability of sight in religious matters that were widespread at the time. ${ }^{16}$

The Southern Netherlandish Wierix brothers were influential proponents of this specific iconography and the meditative use of the religious image. Their full series of cardiomorphic engravings entitled Cor Jesu Amanti Sacrum [The Sacred Heart of Jesus Devoted to the Believer], was produced round I 586 , and used the image of the heart to represent the connection between the viewer and God (fig. I).

Not long after I600, their ideas were picked up by Catholic emblematists in the Southern Netherlands. They either re-used the Wierix brothers' printsas in the case of Gerardus Zoes's Het godtvruchtig herte [The Pious Heart] ( I626) — or modelled their iconography on the same principles that informed the Wierix brothers' prints, as was also done by the Jesuit Jan David in his Veridicus Christianus [The True Christian] (I6or), and Herman Hugo in his Pia Desideria [Pious Wishes] (1624).

The Catholic emblem influenced the literary traditions of various denominations in many European countries. In the seventeenth and eighteenth centuries, at least $\mathrm{I} 500$ reprints, translations, and adaptations of religious emblem books based on Catholic models were produced in European countries outside the Dutch Republic. ${ }^{17}$ The Pia Desideria was adapted into a French Catholic edition (Pieux desires, I 627), and was soon reworked into an English version by the Protestant English poet Quarles (Emblemes, I635), and a Protestant German edition titled Gottseliche Begirde (I 627). ${ }^{18}$ Heart emblems in the tradition

16) Ralph Dekoninck, Ad imaginem: status, functions et usages de l'image dans la litérature spirituelle jésuite du XVIIe siècle (Genève, 2005); and Walter S. Melion, The Meditative Art: Studies in the Northern Devotional Print, I550-I625 (Philadelphia, 2009).

17) The most complete overview of these is provided in Peter M. Daly and Richard G. Dimler, The Jesuit Series, 3 vols. (Montreal, I 997).

18) On Pieux désirs, see Lynette C. Black, 'Popular Devotional Emblematics: A Comparison of Sucquet's Le Chemin de la Vie Eternele and Hugo's Les Pieux Desirs,' Emblematica 9:I (1995), I-20. On Gottseliche Begirde and other German adaptations of the Pia Desideria, see Michael Schilling, "Der rechte Teutsche Hugo." Deutschsprachige Übersetzungen und Bearbeitungen der "Pia Desideria” Hermann Hugos Jesuit,' Germanisch-romanische Monatsschrift 70 (1989), 283-300. A facsimile edition of Quarles's volume complete with introduction has been provided by Karl Joseph Höltgen and John Horden: Francis Quarles, Emblemes (1635) Edward Benlowes Quarlëis and Hieroglyphikes of the Life of Man (I638) (Hildesheim, I993). 


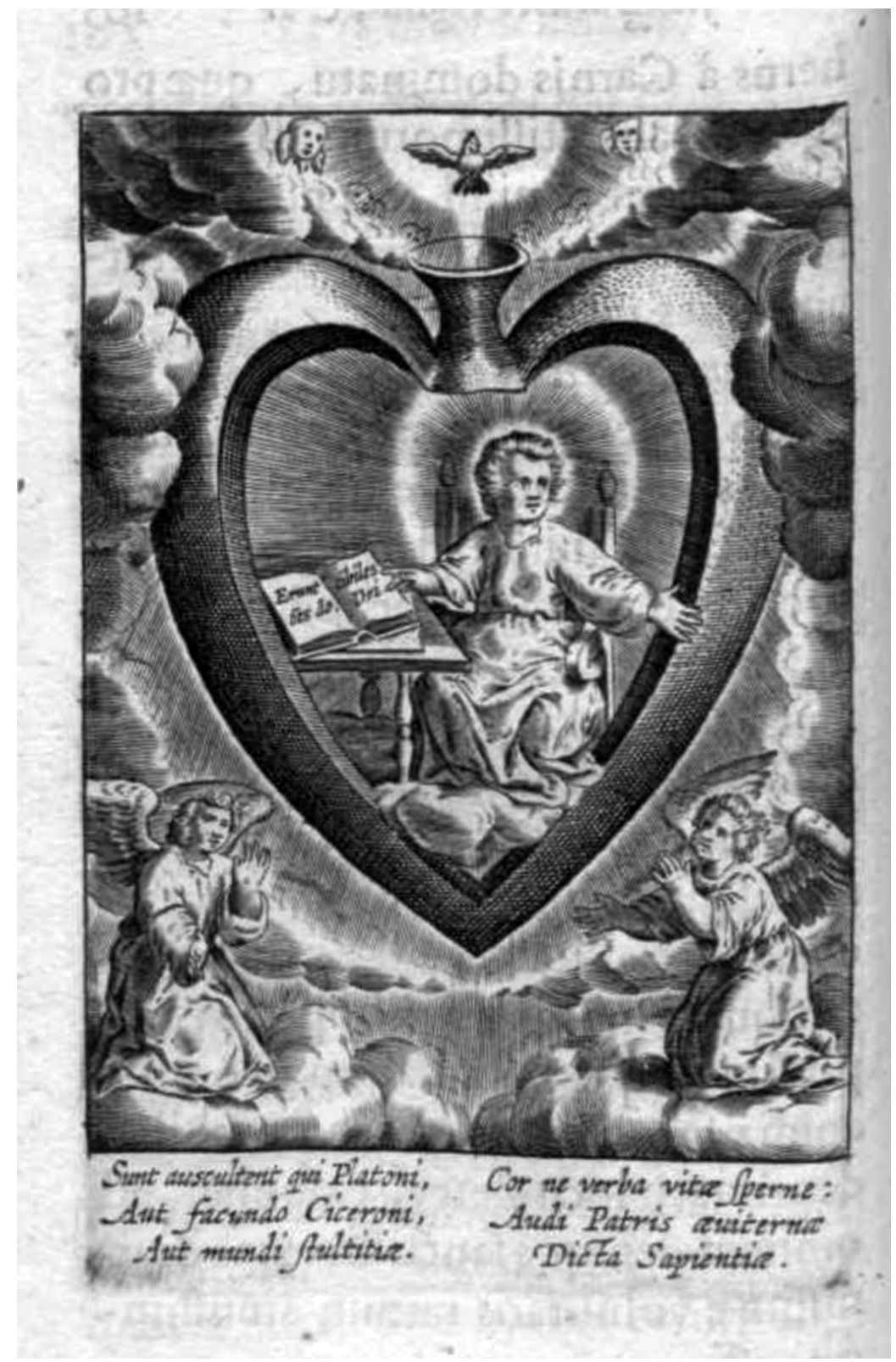

Fig. I. Anton Wierix, print from the series Cor Jesu Amanti Sacrum, as reproduced in Etienne Luzvic, Cor Deo Devotum [...]. Antwerp: Hendrik Aertssens, I628, p. I04. 
of the Wierix prints were created by the English Protestant Christopher Harvey in The School of the Heart (I647) ${ }^{19}$ and by the German Lutheran Pietist Christian Hoburg in his Lebendige Hertzens-Theologie ( 1676 ).

In the Dutch Republic, comparable production of religious emblems based on Catholic models did not take place. Dutch religious emblematics based on the Southern Netherlandish example only began to thrive toward the end of the seventeenth century, when a new impetus was given to the genre in the work of Jan Luyken. His Jesus en de ziel [Jesus and the Soul] (I678) was inspired by Southern Netherlandish models, such as Herman Hugo's Pia Desideria and Otho Vaenius's Amoris Divini Emblemata (1615). ${ }^{20}$ Before I678, the idea of providing religious edification through the emblem had its appeal to the Dutch, for whom the genre of the emblem was one of the major types of visual expression. Attempts to make productive use of the genre on acceptable terms were made by Dutch Protestants from various denominations throughout the seventeenth century, resulting in a compromise: only elements from secular iconographic traditions could be used in Protestant religious emblems up to the i68os.

In the picturae of what was to become the most popular Dutch emblem book in history, the Sinne-en Minnebeelden [Emblems and Images of Love] ( I 6 I 8), the Dutch Reformed emblematist Jacob Cats presented representations of Dutch realia, as seen in many secular emblem books published at the time. Only under the cover of this secular imagery, which avoided distinctly religious iconography, could a religious message be conveyed emblematically. In emblem $2 \mathrm{I}$, for instance, we see a young woman standing next to a table with a caged bird. In the first subscriptio, this scene is given an amorous reading. The reader is warned to keep the bird safely confined: "Ah! tender thing, virginity, so quickly gone!/It vanishes with searching, gets lost when it is found." ${ }^{11}$ Since vogelen ('bird catching') was a term frequently used in the seventeenth century to denote sexual intercourse, the caged bird represented the preservation or protection of virginity (fig. 2).

19) On Harvey's heart emblematics, see Bernard Scholz, 'Emblematic Word-Image Relations in Benedictus van Haeften's Schola Cordis (Antwerp 1629) and Christopher Harvey's School of the Heart (London 1647/1664),' in: Anglo-Dutch Relations in the Field of the Emblem, ed. Bart Westerweel (Leiden, I997), pp. I49-176.

20) On the rise of the religious emblem at the end of the seventeenth century, see Els Stronks, 'Dutch Religious Love Emblems' (see above, n. 9).

21) "Ach! maeghdom, teer gewas, dat ons soo licht ontglijt!/Met soecken raecktet wech, met vinden isset quijt." Jacob Cats, Sinne- en minnebeelden (Rotterdam, I627), p. I 23. 
32)

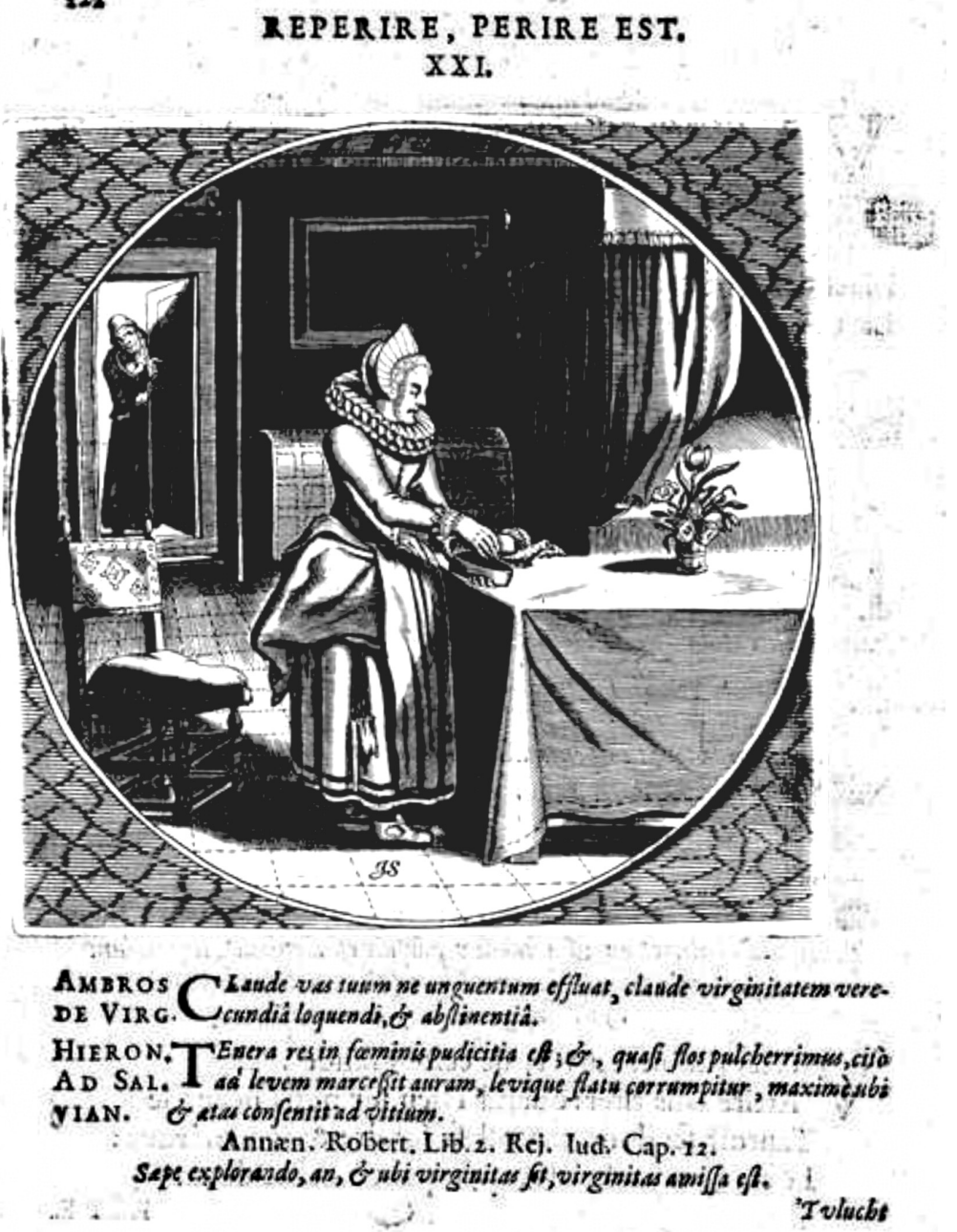

Fig. 2. Pictura "Reperire, perire est" [By seeking, one will die] from Jacob Cats, Sinne- en Minnebeelden. Rotterdam: Pieter van Waesberge, I627, p. I 22. 
Cats makes a smooth transition from the erotic connotation of the image in the first subscriptio to a religious interpretation in the third:

\author{
It is unnecessary to chase a bird from its cage, \\ for it has no desire to stay inside; \\ whenever it spots an opening, \\ it eagerly jumps up and flies away. \\ The body is the cage which keeps the soul imprisoned; \\ Death gives release, it sets the soul free; \\ Why, O Christian heart, why is it then feared here? \\ Though death destroys the body, it liberates the soul. ${ }^{22}$
}

In this religious interpretation, the caged bird represents the human soul, which — given the Christian promise of eternal life-should have the courage to leave the human body behind. Cats codified a format consisting of pictorial realia accompanied by didactic (rather than meditative) subscriptiones. While avoiding distinctly religious iconography, he nevertheless conveyed a religious message emblematically, although the aims of meditation, visual stimulation, and the evocation of emotions remained absent. Cats did not mean his picturae to heighten the soul's awareness of its own image-making power by inviting the viewers to visualize themselves as present in the scene. His images served instead as an aid to religious instruction by evoking instructive guidelines conveyed in the accompanying texts. ${ }^{23}$

As the following two examples will illustrate, the tradition established by the Dutch Reformed Cats was discontinued once other Dutch Reformed emblematists began to find inspiration and support in German Lutheran examples of what were originally Catholic religious emblematics. These emblematists, Hulsius and Boekholt, did not directly appropriate the Southern Netherlandish emblematics, which were in such high demand elsewhere in Northern Europe, but instead followed the example of German Protestant literary traditions in which Catholic emblematic traditions were incorporated. German Lutherans thus functioned as intermediaries in a country where religious

22) “Ten is van gheenen noot een voghel uyt te dryven//Hy wil oock even selfs niet in sijn hutte blyven;/Want als hy maer en siet het open vande lucht//Soo springht hy veerdich op, en gheeft hem totte vlucht./Het lichaem is de koy, die houdt de ziel ghevanghen;/De doot die maecktse los, die maecktse vrye ganghen;/Waerom, o christen hert, waerom doch hier ghevreest?/Al velt de doot het lijf, sy maeckt een vryen gheest." Ibid., p. I26.

23) For a more detailed analysis of Cats's emblematic techniques, Stronks, Negotiating Differences (see above, n. 9), chapter 3. 
tolerance was the norm, exactly the sort of climate in which one would expect different confessional traditions to intermingle and influence each other with little friction.

\section{Bartholomeus Hulsius}

Given the fact that the most popular and influential Dutch Reformed emblematist, Jacob Cats, avoided all association with religious emblematic traditions based on the Catholic traditions which were flourishing outside the Dutch Republic, the Dutch Reformed minister Bartholomeus Hulsius's I63 I publication of the Emblemata Sacra [Sacred Emblems], was a risky undertaking. The prospects for success were poor for Hulsius and his publisher, Lucas Jennis of Frankfurt, for at least two reasons. Cats's model was still highly influential in the Republic, and an earlier attempt to introduce the religious emblem to Protestants in the Dutch Republic by means of appropriating elements of Catholic iconography had already failed when Zacharias Heyns published his Dutch Emblemes Chrestiennes et Morales [Christian and Moral Emblems] in I $625 .{ }^{24}$ Nevertheless, Hulsius's Emblemata Sacra was printed specifically for the Dutch market. Jennis, or perhaps Bartholomeus's brother Friedrich Hulsius, who worked for Jennis at the time, even went to the trouble of translating the Latin quotes into Dutch. ${ }^{25}$ The reason Hulsius's emblems were printed in Frankfurt instead of in the Dutch Republic is probably because Hulsius was born into a publisher's family in Frankfurt in I60I. ${ }^{26} \mathrm{His}$ familiarity with the city's literary milieu perhaps helped him to notice that Lucas

\footnotetext{
24) See Stronks, 'Literature and the Shaping of Religious Identities' (see above, n. 6).

25) As stated by the publisher in the preface to the volume, the Dutch translations of the Latin quotations are "des Druckers oversettinghe." Bartholomeus Hulsius, Emblemata sacra, dat is, eenighe geestelicke sinnebeelden, met niewe ghedichten, schriffuerlycke spreucken, ende bedenckinghen ([s.l.], [s.n.]), fol. * ${ }^{*}{ }^{v}$.

26) At the time the Emblemata Sacra was published, Hulsius was working as a minister in a little village called Cillaarshoek, located between Rotterdam and Dordrecht. This rural place of residence stood in sharp contrast to Hulsius's international background. Born in Frankfurt in I60 I to the engraver Levinus Hulsius, he was a student in Leiden from I 62 I to I626, and in London in I627. For more genealogical details on Bartholomaeus Hulsius, see Simon McKeown, 'A Reformed and Godly Leader: Bartholomaeus Hulsius's Typological Emblems in Praise of Gustavus Adolphus,' Reformation. The Journal of the Tyndale Society 5 (2000), 55-IOI; and Michiel van Groesen, The Representations of the Overseas World in the De Bry Collection of Voyages (I590-I634) (Leiden, 2008), p. 348.
} 
Jennis had produced an intriguing series of religious emblem books between I617 and I624 in his Frankfurt workplace. In I617, Jennis produced the Emblemata NovalEmblemes Nouveau by the Catholic Andreas Friedrich, who worked within the tradition of the Counter-Reformation. Seven years later, he also produced the Emblemata Sacra by the Lutheran pastor Daniel Cramer, who based his picturae on the medieval symbolic tradition of the heart, since the heart was also a central theme in Luther's theology. ${ }^{27}$

Hulsius's Emblemata Sacra relied on realistic imagery prescribed by the pictorial tradition established by Cats, but was otherwise firmly rooted in German literary tradition. The title recalled a volume by Cramer titled Emblemata Sacra. ${ }^{28}$ Furthermore, Hulsius re-used 40 of the Ioo copper plates made by Matthaeus Merian for another German emblem book, Julius W. Zincgref's Emblematum Ethico-Politicorum Centuria, first published in Heidelberg in I6I 9 by Johann Theodor de Bry. ${ }^{29}$

The selected picturae show scenes from daily life as well as landscapes, combined with some allegorical elements. In contrast to Cats, Hulsius intended his images to function as aids to meditation: they did not serve as (arbitrary) starting points for edifying moralizations but instead were meant to be studied for their specific meditative potential. Following the example set by Cats, Hulsius selected 40 picturae from the 100 in Zincgref's volume, specifically those depicting scenes from daily life. ${ }^{30}$ Hulsius explained that these images were to be used in one's "H. Meditatien" [Holy Meditations] throughout the day. ${ }^{31}$ Hulsius maintained in his "Dedication" that human beings could "learn to know God, the Maker of themselves and all other creatures, from the visible things of His creation, (as if from a large book written with many letters)." 32 In the past, this had not been comprehended by the heathens who remained

27) Jennis's religious emblematic production is discussed in more detail in Els Stronks and Bert Both, 'Acceptatie van het vreemde: pers- en geloofsvrijheid in de Republiek vanuit internationaal perspectief,' Nederlandse letterkunde I 5:2 (2010), 73-102.

28) See also Dietmar Peil, 'The Emblem and the German-Speaking Regions,' in A Companion to Emblem Studies, ed. Peter M. Daly (New York, 2008), pp. I94-195.

29) Hulsius rejected for instance picturae depicting violent scenes which suited Zincgref's political intentions, but were of no use to Hulsius (such as Zincgref's pictura III [predatory bird], V [fighting lion], XIV [a bull fighting a bear]).

30) See Van der Coelen, De Schrift verbeeld (see above, n. 8), p. I63.

31) Hulsius, Emblemata Sacra (see above, n. 25), p. I 52.

32) "opdat de Mensche uyt de Scheppinghe der sienlycker Creaturen (als uyt een groot Boeck, met soo veele Letteren beschreven) soude leeren kennen Godt synen, ende aller Creaturen Schepper [...]." Ibid., fol. * $3^{\mathrm{r}}$. 
1.22

\section{XXXTV.}

MAerons beeffi Godt gheopenbicre door fjizen Geeff. Want de Geeft: onderfoeckt alledingh, oock dé diepten Godts: W ant vvan Menfiche vveet, vvat in den Menfshe is, dan de Geeft des. Menfshen, die in


Wiecant' Herte doorgrondien: Ide de Heere bent, die, C.c.Jer.17.9.

onder fockt u felven, beproef tu felven, of ghyin den Gheloovefyt, offeniet: Weet ghy niet, dat Chriffwin u is? 2. Cor.13.

Godts Sinfyn Gceftonsopenbaers:

Deorfoeckt dan hocuherte vaert.

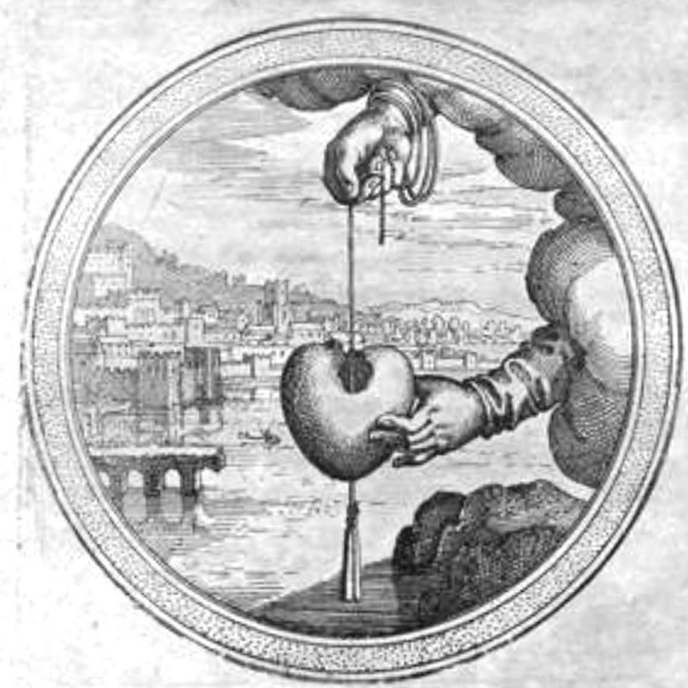

T.

Rom.11. Hoecomede Menfch dascraen' van Godes Sintekennen

34. Hoe canhy leker zyn van fyne faligheyt?

1. Cor. 2.15, Hoe come fyn hert geruft, wie heeft hiem fulck's gefeyt?

16. Dats' $x^{\prime}$ vraeghen van die gen, die defe Leer ontkennen.

Fig. 3. Pictura XXXIV from Bartholomeus Hulsius, Emblemata Sacra, dat is, eenighe geestelicke sinnebeelden, met niewe ghedichten, schriffuerlycke spreucken, ende bedenckinghen. [s.l.]: [s.n.], p. I22. 
"blind to things of God's Spirit." 33 For this reason, God gave man the Bible, "as well as the Light of Scripture, the true light, which opens our eyes so that we see the wonders of the world and of God's Law." ${ }^{4} 4$ The emblems in his volume, Hulsius argued, were designed to "convert readers, or to help them make progress on the road to sanctification." 35 According to emblem XXXIV, the insights readers gained from studying these emblems - both in their visual and textual components — should be used to examine their hearts. In this pictura, a hand holding a string with a heart attached to it reaches down from the clouds, lowering the heart to the earth (fig. 3).

Hulsius uses this image to convince readers of the need to search for dishonesty in their hearts. If they do so, they will undoubtedly come to the conclusion that "the deceit within the human heart is great and manifold." 36 Knowledge of one's own soul opens up the possibility of learning more about God-a premise underlying almost all Protestant forms of meditation. ${ }^{37}$

Hulsius aimed not only to develop the personal faith of his readers, but also to influence the Dutch Reformed Church as a whole. In emblem XXIX, for instance, the pictura shows two hands being sprayed with water by a third hand reaching from the clouds (fig. 4). In the accompanying poem, Hulsius argues: "As seen in the hands depicted here:/If one [hand] washes the other, both are cleaned//Help your fellow human being and you will not regret it". ${ }^{38}$

In the prose text that follows the poem, this advice is specifically applied to church members, the message being that by working together, they can purify God's church. Even though Hulsius's picturae contained realistic elements rather than elements from religious iconographies, his images were meant to serve as stimuli for a meditative process, inviting the readers to see and feel their own hands washed by the water dripping from heaven.

\footnotetext{
33) "blindt in die dinghen, die des Geestes Godes zijn." Ibid.

34) "ende licht der Schrifttuere, het rechte licht, waerdoor ons de Ooghen worden gheopent, soo dat wy sien de Wonderenheyd van de Werelt, en wet Godes." Ibid., fol. * $3^{\mathrm{v}}$.

35) "een siele te winnen ofte om selver in den Wegh der Saeligheyt gevoordert te worden." Ibid., fol. * $3^{\mathrm{r}-\mathrm{v}}$.

36) “T’bedrogh van s'Menschen hert is groot, en menighfout." Ibid., p. I 24.

37) As argued in Barbara Kiefer Lewalski, Protestant Poetics and the Seventeenth-Century Religious Lyric (Princeton, I 979), p. I 49; and also in Dyrness, Reformed Theology and Visual Culture (see above, n. II), pp. 83-84.

38) "Soo aen dees handen blyckt, die hier geschildert syn//Als s'eene d'andre wascht, dan worden beyde reyn//Helpt mensch u medelidt en willtet niet bedroeven." Hulsius, Emblemata Sacra (see above, n. 25), p. Ioo.
} 


\section{XXIX.}

WW 1 zijn vvel vele leden, maer een Lichaem: end de Ooghe en can totter handt niet fegghen, ick en behoeve wniet, $6 c$. I. Cor. 12 .

\subsection{1,12,14.}

Ick vvafche myne Handen in Onf chuld.Pfal.73.13.

Salich zijn dic, diercyn van Herten zijn. Matth. 5.8.

Gelyck deen fuyvert danderhandt,

Doet deenden andernonderftandt.

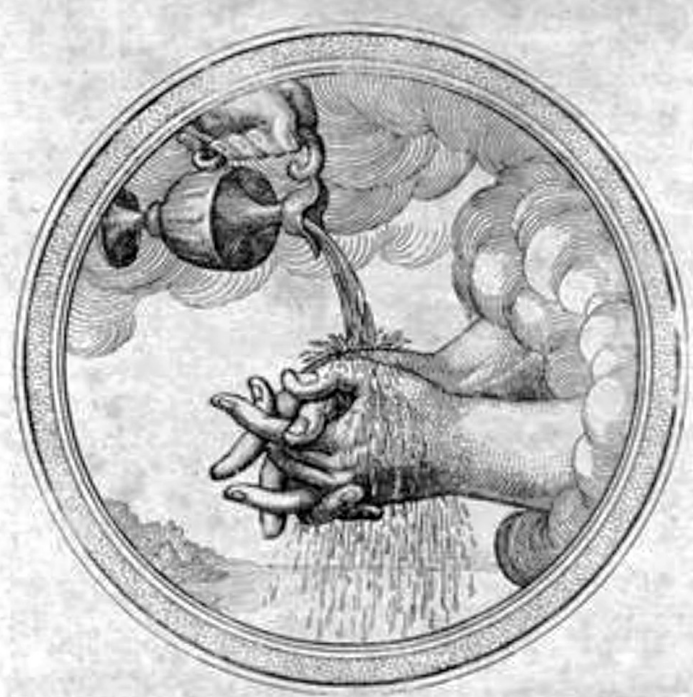

I.

[a] Int Lichaem d'eene Lidtherandre doet behoeven,

Soo aen dees handen blyckt, die hier gefchildert $\mathrm{fyn}_{2}$

Als deene d'andre vvafcht, dan vvorden beyde reyn,

Helptmenfchumedelidten wiltterniet bedroeven.

Fig. 4. Pictura XXIX from Bartholomeus Hulsius, Emblemata Sacra, dat is, eenighe geestelicke sinnebeelden, met niewe ghedichten, schrifftuerlycke spreucken, ende bedenckinghen. [s.l.]: [s.n.], p. Ioo. 
Hulsius was anxious not to stir up animosity. To avoid creating the impression that he was advocating a use of images similar to the Catholic conventions, he discussed the issue of God's invisibility in emblem XVI. The pictura of the sun shedding light on a stretch of water is explained in the texts: we can never see God face to face, just as we can never look directly at the sun, because it would do us harm. We can look at indirect representations of Him, but not the kind of images the Catholics worship:

\author{
When God revealed His Glory to Israel \\ And addressed His people, they were terrified, \\ This is why God now addresses us through His teachers, \\ Because if $\mathrm{He}$ did so in person, we would hardly survive it. \\ God cannot be seen, other than through His word, and His works, \\ These are like shadows, His true being is known to no one \\ So why do you paint, or carve in wood, \\ Him who is eternal, you Papists in your churches. ${ }^{39}$
}

To prevent association of his work with the Catholic use of images, Hulsius explains every nuance of the scenes depicted in the picturae. In doing so, he minimizes the chance of misinterpretation, presenting his reading of the visual stimuli almost as factual knowledge. By addressing all elements of the picturae, explaining them while also limiting their interpretation, Hulsius presents the image as a univocal carrier of meaning.

Despite his efforts to adapt his emblematic concept to the Dutch situation, Hulsius's Emblemata Sacra was not successful. His Emblemata Sacra went virtually unnoticed by readers in the Dutch Republic. ${ }^{40}$ The new religious emblem books made by Cats in the I640s bore the stamp of occasional meditations like Hulsius's Emblemata Sacra, with their emphasis on the inner experiences of Reformed doctrine and the sanctification of one's personal life, but for the

\footnotetext{
39) “Doe Godt aen Israel syn Heerlickheyt liet blycken/En t'volck sprack selver aen, het was te seer verveert//Dats d'oorsaeck dat ons Godt door syne Leeraers leert//Want dat hyt selver waer, wy souden haest beswycken./God can niet syn gesien, dan door syn woordt, en wercken//Dat syn als schaeduwen, syn wesen niemant weet/Wat schildert ghy hem dan, oft op een houdt afmeet//Hem, die oneyndigh is, ghy Paepen in u Kerken!" Ibid., pp. 4546.

40) On the popularity of Quarles's emblems, see Aakansksha Virkar-Yates, 'The Emblematic Sources of Gerard Manley Hopkins's the Wreck of the Deutschland (I 876), Literature and Theology 22:I (2008), 32-47.
} 
most part they were unillustrated. For the time being, the Dutch Reformed religious emblem could only thrive as emblemata nuda, emblems without pictures. ${ }^{41}$

In accordance with this tradition, Hulsius's second emblematic work was just as meditational in nature as his first, but it was issued without picturae. ${ }^{42}$ The book was published in Amsterdam in I642; a place generally regarded as a hybrid melting pot, but in fact significantly less open to innovation than Jennis's Frankfurt. ${ }^{43}$ While Jennis reaped the benefits of Frankfurt's tolerant and open political climate, it is unlikely that Hulsius would have been able to find a Dutch printer to publish a volume of religious emblems with illustrations. This is probably what led him to choose Jennis, despite the practical problems this decision brought with it. ${ }^{44}$

\section{Johannes Boekholt}

A few decades later, another Dutch Reformed emblematist with a special connection to Germany set out to transform the visual traditions. Johannes Boekholt lived and worked in Amsterdam, but his family roots were in Germany; Boekholt's grandfather had moved to the Dutch Republic in the I630s. ${ }^{45}$

41) Only the emblems concerned with human pursuits as opposed to religious subjects were illustrated in Cats's emblem books of the I640s and I650s, as argued in Karel Porteman, 'Cats's concept of the Emblem and the Role of Occasional Meditation,' Emblematica 6 (1992), 65-82.

42) In 1642, Hulsius's Den Onderganck des Roomschen Arents door den Noordschen Leevw [The Downfall of the Roman Catholic Eagle Caused by the Northern Lion] was published, a collection of emblems that explore the emergence of Sweden as a great European power, responsible for maintaining the political and religious balance in Europe. See for more details McKeown, 'A Reformed and Godly Leader' (see above, n. 26), 55-Ior.

43) On Amsterdam's advanced position see Peter Burke, Cultural Hybridity (Cambridge, 2009), pp. 73-74.

44) On the political and religious situation in Frankfurt at the time Jennis was in the publishing business, see Anton Schindling, 'Wachstum und Wandel vom Konfessionellen Zeitalter bis zum Zeitalter Ludwigs XIV. Frankfurt am Main I 555-I68 5,' in Frankfurt am Main. Die Geschichte der Stadt (Sigmaringen, 1994), 205-260. The practical difficulties of working with Jennis are described in the foreword to Hulsius's Emblemata Sacra (see above, n. 25).

45) J.B.H. Alblas, 'Johannes Boekholt (1656-1693),' in Figuren en thema's van de Nadere Reformatie, ed. J.B.H. Alblas et al. (Rotterdam, I993), p. 87. 
In I686, Boekholt produced his first religious emblem book based on the Catholic iconographic traditions. His Levendige herts-theologie [Spirited Theology of the Heart] was, according to its title page, "previously rendered in German." ${ }^{46}$ Boekholt's main source had been the Lebendige Hertzens-Theologie by Christian Hoburg, a pastor in the German Lutheran Church, controversial for his open advocacy of mysticism. ${ }^{47}$ The first edition of Lebendige HertzensTheologie was published in I676 in Amsterdam, by the German printer Hendrik Beets, whom Hoburg had met while they were both living in Amsterdam. ${ }^{48}$

The Lebendige Hertzens-Theologie comprised an intriguing series of emblematic images and mystical texts, intended to move readers to sacrifice a fervent love of their hearts in inner prayers to Jesus. Hoburg's picturae were inspired by the Wierix prints for Cor Jesu Amanti Sacrum, to which he added new texts, both short poems as well as "Seelen-gespräche" [conversations of the soul] in prose. For example, an image of a heart being pierced by arrows is accompanied by the following confession:

Now, my Jesus / now that you have assured me/ of Your willingness to do this for me/I now offer to you this hour and this moment/yes, my heart/ as voluminous and as little as it is; Ay, affect my heart with the tremendous arrows of Your fiery love/so that it is gloriously wounded/indeed totally ablazed and glowing by Your flaming arrows, loving nothing or no-one but You. ${ }^{49}$

In Levendige herts-theologie, Boekholt incorporated the same images that Hoburg had used based on the Wierix prints (as reproduced in this 1736 edition) (fig. 5).

46) "Wel eer in 't Hoogduyts voorgestelt." Christian Hoburg, Levendige herts-theologie (Amsterdam, I686), title page.

47) See, for example, Mirjam de Baar, 'Ik moet spreken': Het spiritueel leiderschap van Antoinette Bourignon (I6I6-I680) (Zutphen, 2004), pp. 317 and 551.

48) Dimler and Daly, The Jesuit Series (see above, n. I7), number J922.

49) "Nun mein JESU/weil ich versichert bin/daß du dieses thun wilt/ siehe so präsentire ick dir diese Stunde und Augenblick/ja ergebe dir mein Hertz/so groß und klein es ist; Ach verwunde es mit den gewaltigen Pfeilen deiner feurigen Liebe/daß es von dir seliglich verwundet/ja von diesen deinen feurigen Pfeilen ganß in Liebe feurig und gluend werde / daß es nicht mehr lieb habe die Welt/ und was in der Welt ist/sondern dich allein.” Hoburg, Lebendige Hertzens-Theologie Das ist Andächtige Betrachtung wie Jesus im Hertzen wohne und würcke und im Hertzen der Liebhabenden sey Alles was first printed in Amsterdam in I676. The quote is from the I69I reprint, published in Frankfurt, pp. 80-8 I. 


\section{Herts-Theologie.}

\section{Figuur.}

\section{Hier verwondet Jesus het Herte.}



Als gy myn herteHeer met liefde fult doorwonden, Soo zal den luft wel haaft vergaan tot d'ydelheid, Enal onnutte vreugd' die zal tot allen ftonden, Verdwynen uyt myn Ziel, met alle ydelheyd.

\section{Zie.}

Fig. 5. Pictura XVI from Christian Hoburg, Levendige herts-theologie. Amsterdam: Verheijden, I736, p. I39. 
Boekholt also used Hoburg's text, reproducing it in a more or less literal translation:

O sweet Jesus, at this hour and moment I offer my heart to you, as voluminous and as little as it is: ay, affect my heart in such a manner with Your love that my heart will burn with love for You and my fellows. ${ }^{50}$

Due to underlying practical issues, Boekholt did not re-use all of Hoburg's picturae. In his Lebendige Hertzens-Theologie, Hoburg had contributed new plates to the Wierix series. Boekholt worked with the copies of the Wierix plates that were circulating in Amsterdam at the time, but apparently decided not to invest in reproductions of Hoburg's additional plates. ${ }^{51}$

As Boekholt maintained in the preface to his Levendige herts-theologie, the meditational purposes of his adaptation surpassed those of the German original. He had added many poems that could be employed in the readers' meditations: "As we should explain to our reader, this work is almost half doubled, enlarged with new verses which are printed for and after each picture."52 Boekholt's stylistic and compositional choices closely resemble another German emblem book stemming from the Pia Desideria tradition, which was also current in Amsterdam at the time: the Göttliche Liebesflamme [Divine Love Flames] (165I) by Johann Michael Dilherr and Georg Philipp Harsdörffer, which was itself based on yet another devotional work, the Christliche Andachten, Gebet und Seuffzer [Christian Meditations, Prayers and Sighs] by Dilherr, published in Jena in I640.53

In the Christliche Andachten, a collection of twenty meditations on the Song of Songs, Dilherr, a pastor in the German Lutheran Church, emphasized the need for the spiritual enhancement of one's faith. In this, he fol-

50) "O goede Jesus, op dese ure en oogenblik presenteere, ende geve ik u myn herte, zoo groot en kleyn als het is: ach verwondet het selve doch soodanig door uwe Liefde, dat het tegen $\mathrm{U}$ ende mynen Naasten in liefde brandende worden moge." Hoburg, Levendige hertstheologie (see above, n. 46), pp. I 40-I4I.

51) See Daly and Dimler, The Jesuit Series (see above, n. I7), number J9r 2. See also Mirjam de Baar, 'Hartsemblematiek in Swammerdams studie van de eendagsvlieg,' De zeventiende eeuw 21:2 (2005), 3 I 2-334.

52) "Wy sullen den Leser noch seggen, dat dit Werk meer als de helft vermeerdert is, en vervult met nieuwe Versen, welke voor yder Verbeelding staan, en daer na volgen." Hoburg, Levendige herts-theologie (see above, n. 46), fol. A8 .

53) Gerhard Dünnhaupt, Personalbibliographien zu den Drucken des Barock [Hiersemanns bibliographische Handbücher 9], 6 vols. (Stuttgart, I990-1993), 2:1 271, number 60.I. 
lowed the example of the German Lutheran writer Johannes Arndt. ${ }^{54}$ Dilherr moved to Nuremberg in I642, where he joined the literary society Pegnesischer Blumenorden [The Order of the Flowers on the Pegnitz]..$^{55}$ One of the members of this society, Harsdörffer, took it upon himself to produce a second edition of Dilherr's Christliche Andachten in I65 I, giving it the new title Göttliche Liebesflamme. ${ }^{56}$ Harsdörffer expanded Dilherr's twenty meditations with emblems, poems, and songs in Pia Desideria style. ${ }^{57}$ Several of the picturae of the Göttliche Liebesflamme were based on Pia Desideria imagery, while Harsdörffer himself penned the new poems and songs. ${ }^{58}$ The German edition was reprinted in the Dutch Republic by the Nosche family of Amsterdam in 1667 and $1672 . .^{59}$ It is highly probable that Boekholt was well-acquainted with these productions, which had been printed in what was more or less his backyard.

Boekholt's additions to his edition of Hoburg's Lebendige Hertzens-Theologie appear to have been inspired by the concept of Dillher's Göttliche Liebesflamme. ${ }^{60}$ In Boekholt's Levendige herts-theologie, all of Hoburg's meditative texts - the conversations of the soul—are preceded by a poem and a pictura, and the picturae are often followed by another meditative prose text, such as a song, an extra poem, a Bible quotation, or an "aanmerking" [observation].

54) Willard James Wietfeldt, The Emblem Literature of Johann Michael Dilherr (I604-I669). An Important Preacher, Educator and Poet in Nürnberg (Nuremberg, 1975), p. I 8; Paul P.M. Raasveld, Pictura, poesis, musica. Een onderzoek naar de rol van de muziek in embleemliteratuur (Utrecht, I995), pp. I25-I 26.

55) The relationship between Dilherr and the Pegnesischer Blumenorden is dealt with in Wietfeldt, The Emblem Literature of Johann Michael Dilherr (see above, n. 54), chapter III; and Stefan Ehrenpreis, 'Teaching Religion in Early Modern Europe: Catechismus, Emblems and Local Traditions,' in Religion and Cultural Exchange in Europe, I400-I700, ed. Heinz Schilling and István György Tóth (Cambridge, 2006), p. 269. Although Dilherr was not a member of the society, he was heavily involved in the society's activities.

56) Dünnhaupt, Personalbibliographien (see above, n. 53), 2:I27I-I273, number 60.260.8 .

57) Raasveld, Pictura, poesis, musica (see above, n. 54), pp. I 25 -I 32.

58) Wietfeldt, The Emblem Literature of Johann Michael Dilherr (see above, n. 54), pp. 7283; Raasveld, Pictura, poesis, musica (see above, n. 54), pp. I $25-\mathrm{I} 32$.

59) Johann Michael Dilherr and Georg Philipp Harsdörffer, Göttliche Liebesflamme: Das ist/Christliche Andachten/Gebet/und Seufftzer/über Das Königliche Braut-Lied Salomonis [...] (Amsterdam, 1672). See Dünnhaupt, Personalbibliographien (see above, n. 53), 2:1 272, number 60.7. The Göttliche Liebesflamme may have been introduced in the Dutch Republic by Philipp von Zesen, another member of the Pegnesischer Blumenorden, who lived in the Dutch Republic for a number of years.

60) Wietfeldt, The Emblem Literature of Johann Michael Dilherr (see above, n. 54), pp. $72-$ 83; Raasveld, Pictura, poesis, musica (see above, n. 54), pp. I 25 -1 32. 
By adding these new texts and images, Boekholt enhanced the spiritual nature of Levendige herts-theologie. Boekholt's "Hier doorsoekt Jesus het Herte," for instance, is a true copy of Hoburg's fourth emblem, "Hie durchsuchet Jesus das hertz" [Jesus Is Now Examining the Heart]. Both contain a pictura depicting amor divinus examining the soul's heart with a lantern, as well as this conversation in prose: ${ }^{61}$

Hoburg's version:

My soul, the Creator and Saviour of your heart, has to examine it on His own, going through all corners of your heart with his lamp, and revealing all the evil that he discovers. ${ }^{62}$

Boekholt's version:

My soul, the Creator and Saviour of your heart, has to examine it on His own, he went through all the corners of your heart with his lamp, and has revealed all evil that he discovered. ${ }^{63}$

Boekholt's version enlarges upon Hoburg's through the inclusion of poems, a song and a sigh, all expressed by a speaker who devotes himself to Jesus:

Oh faithful Jesus! good Lord!

How are you searching my heart,

Sometimes its bottom end, sometimes its top end,

Through all most hidden and deepest corners.

What do you find, oh Friend of the Soul!

Other than scorpions and snakes,

All the things that you do not love,

And which are hurtful to the heart. ${ }^{64}$

61) See Hoburg, Lebendige Hertzens-Theologie (see above, n. 49), p. I8; Hoburg, Levendige herts-theologie (see above, n. 46), 36.

62) "meine Seele/der Schöpffer und Erlöser deines hertzens muß es allein durch gründen; Er muß mit seiner Latern alle Winckel deines hertzens durchsuchen/ und was Er Unreines darinnen findet/dir anweisen." Hoburg, Lebendige Hertzens-Theologie (see above, n. 49), p. 20.

63) "myn Ziele, de Schepper ende Verlosser uwes herten, kan ende moet datselve alleene doorgronden, hy moet met sijn klaarschijnende Lanteerne sijnes Geestes, alle heymelijken hoeken uwes herten door-soecken, ende wat hy onreyns daar in vindet, u aanwijsen." Hoburg, Levendige herts-theologie (see above, n. 46), pp. 38-39.

64) "O Trouwe Jesu! goede Heer!/ Hoe komt gy nu myn hert doorsoeken, / Dan onder en dan boven weer, // Door al de schuylste en diepste hoeken. / Wat vind gy daar, ô Zielen 
Judging from Boekholt's preface to the Levendige herts-theologie, he was especially intrigued by Harsdörffer's idea that not only the eyes, but also the ears could expand the possibility of learning more about God. Harsdörffer maintained that "Visus est sensus Inventionis. Auditus sensus informationis" ("Sight is the sense of the imagination. Hearing the sense of education"). ${ }^{65}$ Boekholt presented the similar idea that hearing could also be a means to expand knowledge - a step Hoburg had not taken in his Lebendige HertzensTheologie:

Oh what erudition did divine and unpretentious people have, to devote all of their activities to Jesus' word only, in order to climb the Tabor with him to experience the nature of the master they followed, on the testimony of God, who said: This is my loving Son, I have pleasure to him, Hear Him.

\section{[...]}

In this little treatise you will find the kind of materials and figures which only belong to people who are enlightened by God's Spirit, which enlightenment is needed to understand what has been given by God. You will find all concealings of the heart. ${ }^{66}$

The Levendige herts-theologie stood on the threshold of Boekholt's emblematic production inspired by German models. Boekholt produced his second collection of religious emblems in I691, the Goddelyke liefde-vlammen. Both its title and composition connected it to its German predecessor. ${ }^{67}$ In 1693 , Boekholt published a third emblem book, entitled 't Geopende, en bereidwillige herte [The Open and Willing Heart]. ${ }^{68}$ In the preface to this volume,

Vrind!/ Als scorpioenen ende slangen, / Al 't gene dat gy niet en mint, / En dat het Herte komt te prangen." Ibid., p. 36.

65) Dilherr and Harsdörffer, Göttliche Liebesflamme (see above, n. 59), fol. B2v'.

66) "O wat geleertheyd besaten die Goddelijke eenvoudige Zielen, welke op 't woord van een eenige Jesus, haar besigheyd en handel verlieten, om met hem te klimmen op Tabor, en daar te aanschouwen wat meester sy volgden, met het getuygenis van God, welke seyde: Dese is myn geliefden Soone, in de welke ik een welbehagen hebbe, Hoort Hem. [...] Gy sult vinden in dit Tractaetje sulcke zaken en gestaltenissen, welke maar alleen eygen zijn die geene welcke God door sijn Geest inwendig heeft verlicht, om te begrijpen die dingen welke haar van God geschonken zyn. Gy sult 'er in vinden de gantsche verborgene gestalte des herten." Hoburg, Levendige herts-theologie (see above, n. 46), fol. A6 ${ }^{\mathrm{v}}-\mathrm{A} 7^{\mathrm{v}}$.

67) John Landwehr, Emblem and Fable Books printed in the Low Countries $1542-1813$, 3rd ed. (Utrecht, I988), pp. I 3 I-I32, number 314-3 I6, 459-46I.

68) These two volumes are briefly explored in Porteman and Smits-Veldt, Een nieuw vaderland voor de muzen (see above, n. 7), p. 865 and in J.B.H. Alblas, Johannes Boekholt 
Boekholt urged readers to offer their hearts and souls to God through profound engagement with the images. ${ }^{69}$

\section{Conclusion}

As can be concluded from the Boekholt case in particular, the Wierix prints were used by the Dutch Reformed Church only after they had passed through German hands. Emblem books based on the Wierix brothers' Cor Jesu Amanti Sacrum, which had been produced in the Southern Netherlands, were never published in any shape or form in the Dutch Republic. German traditions thus played a decisive role in the development of Boekholt's emblematic production.

We can only speculate as to why German applications of allegorical imagery were more readily accepted than their Southern Netherlandish predecessors. The Catholic images may have been deemed a more acceptable means of religious instruction for the Dutch Reformed, because once they had been appropriated and adapted by German Lutherans, the images were transformed into stimuli for a practice of piety which was more closely related to Dutch Reformed traditions than to Catholic traditions. For instance, the preface to the Göttliche Liebesflamme, one of Boekholt's main sources of inspiration, explicitly stated that only the use of the ear could give access to knowledge, whereas the eye could only support the initial examination of divine subjects. ${ }^{70}$ This transformed consideration of the suitability and applicability of religious imagery in the practice of piety could have facilitated its appropriation by the Dutch Reformed tradition.

The two cases we have discussed here still do not exhaustively explain the seemingly paradoxical status of restrictiveness in the Dutch Republic. The Republic was renowned for its religious tolerance, but within its borders, rapprochement between the visual traditions dominated by the Catholic and Protestant literary cultures was, in the two cases discussed here, not easily achieved. The stimuli provided by forms of German-Dutch exchange appear to have been crucial to the process of rapprochement.

(1656-I693). The First Dutch Publisher of John Bunyan and Other English Authors ([s.l.], i987), e.g. pp. 104-105, 238-24I.

69) "Beschouwd dan in dese afbeeldinge u selfs." [Examine your own reflection in these images] Johannes Boekholt, Geopende, en bereidwillige herte (Amsterdam, I693), fol. A6r.

70) "Visus est sensus Inventionis. Auditus sensus informationis" [Sight is the sense of the imagination. Hearing the sense of education]. Dilherr and Harsdörffer, Göttliche Liebesflamme (see above, n. 59), fol. B2 ${ }^{\mathrm{v}}$. 
More research is required to explain this situation: were impulses from other countries where visual literary cultures developed more rapidly (such as England and France) just as important for Dutch developments? Increased attention to forms of crosscurrents in religious imagery between Germany and the Dutch Republic, as well as between other Northern European countries, could reveal the specifics of the international dynamics of the spread and development of a new visual culture. Possible exchange between the literary traditions of various denominations in various countries has rarely been discussed from an international perspective, but research of this kind can reveal underlying ideological processes. Consideration of the process of production in relation to the process of literary and pictorial appropriation promises new insight into European religious cultures, as the two cases discussed in this article intend to demonstrate.

It is our expectation that additional case studies will shed more light on the way illustrated religious books functioned in evolving Northern-European societies: illustrated religious texts were the products not only of authors, engravers, and publishers, who worked in a field combining the textual and visual arts, but were also formed and shaped by theological debates and confessional traditions. They shaped the relationship between individual citizens on the one hand and these debates and traditions on the other, and allow us to analyze demarcations between religious cultures in various European countries.

Feike Dietz

F.M.Dietz@uu.nl Utrecht University

Els Stronks

E.Stronks@uu.nl Utrecht University 